\title{
The Influence of gender disparities in the Employment Sector on Economic Growth in Indonesia
}

\author{
Sri Endang Rahayu', Puchong Senanuch ${ }^{2}$ \\ \{sriendang@umsu.ac.id ${ }^{1}$ \} \\ ${ }^{1}$ University of Muhammadiyah Sumatera Utara, Medan, Indonesia Jalan Kapten Mukhtar Basri \\ No. 3 Medan, Indonesia \\ ${ }^{2}$ Thammasat University, Thailand
}

\begin{abstract}
The economic situation of a region can be seen from the level of economic growth. Increased economic growth will be more effective when coupled with an increase in the quality of human resources and reduced inequality between men and women both in their roles and the acquisition of rights to economic growth. The purpose of this study is to analyze the gap between the value of the Gender Development Index and the Human Development Index which influences economic growth and to estimate gender equality towards economic growth. The results of this study are that 1). Female Labor Force variables have a negative and significant influence on economic growth in Indonesia, 2) the gender development index variable has a positive and significant relationship to economic growth in Indonesia and 3) Based on the estimation model, namely the Employment Departure female variable and the Gender Development Index variable influences Growth Economy in Indonesia, with R2 value of 0.048987.
\end{abstract}

Keyword: Gender disparities, the field of employment, Economic Growth

\section{Introduction}

One of the goals of the Millennium Development Goals is gender equality and women's empowerment which are eight objectives declared by the United Nations in 2000. The Millennium Development Goals are the declaration of the millennium as agreed by the head of state and representatives of 189 countries where the target is people's welfare and community development in 2015. Indonesia is a member of the United Nations which also carries out the objectives of the Millennium Development Goals, namely achieving gender equality to improve the quality of human resources without differentiating between men and women.

"The relation between gender inequality and economic growth is complex and covers several plausible direct and indirect links"(Schober and Winter-Ebmer, 2011). According to Mosse (2003) that: "fundamentally, gender is different from biological sex. Biological sex is a gift; humans are born as a man or a woman. However, the process that makes a person masculine or feminine is a combination of basic biological building blocks and biological interpretation by one's culture. Gender is a set of roles which, like costumes and masks in the theater, convey to others that someone is feminine or masculine. This special behavioral tool which includes appearance, attitude, personality, working inside and outside the household, sexuality, family responsibilities and so on jointly polishes one's gender role. These gender roles change over time and differ from one culture to another".

"Gender is a set of roles, behaviors, activities and attributes that are considered appropriate for men and women. Gender refers to a community's constructed role and learned behaviors and expectations that are linked to women and men. Like race, ethnicity, or class, 
gender is a social category that most determines the opportunity for life and one's participation in society and the economy. Gender roles and relationships can vary greatly from one community to another. Gender roles and relationships develop from interactions that occur between various biological, technological, economic, and other social constraints" (World Bank, 2005).

The Central Bureau of Statistics noted that in 2017, the population in Indonesia was 198.77 million, of which the male population was more dominant than the female population. Data obtained from the 2017 Central Bureau of Statistics shows that the number of male population is 99.98 million while the female population is 98.79 million.

(Economics, Study and Diponegoro, 2014) explain that "Human Resources (HR) or Human Resources contain two meanings, namely the first human resources contain the meaning of work or service that can be provided in the production process, secondly human resources are related to human beings able to work to provide services or business ventures. Work means being able to carry out activities that have economic value, namely that these activities produce goods or services to meet the needs of the community. Physically the ability to work is measured by age, in other words people in working age are considered capable of working. The population group in working age is called labor or manpower. In short, labor is defined as a population in working age ". The workforce is a population aged 10 years and over who is able to be involved in the production process. According to the National Labor Force Survey, "the workforce is a working age population who has a job, both those who work and temporarily do not work because of a reason such as waiting for harvest, employees who are on leave and the like. Besides that, including the workforce are those who do not have jobs but are looking for / expecting jobs and people who already have jobs but have not started work or in other words unemployment.

In 2016 the number of the workforce in Indonesia was dominated by the male workforce, which amounted to 78,138 while the female labor force was 49,534 . It can be said that the number of male labor force is greater and more dominant than the female workforce, where the number of male labor force is 282.55 million and the female workforce is 173.17 million. This shows that the workforce between men and women still has a gap.

Apart from data on the number of labor force based on age group and gender gender disparity can also be seen from the data on the percentage of the population working according to the formal/ informal sector and gender. "There has been a significant increase in the rate of working of women in the formal and informal sectors. However, there have not been subsequent changes in the doing of social reproductive work".(Rai, Brown and Ruwanpura, 2019)

According to Ulung Purba (2016) that "The structure of the female labor force has a low level of education. Thus, most women are still engaged in the informal sector or jobs that do not require the quality of sophisticated or specific knowledge and skills. The work of women in the informal sector usually lacks guarantees of legal protection and guarantees of adequate welfare, in addition to poor working conditions and low income ".

The data shows that the formal and informal sectors are still dominated by men. 2016 National Sakernas shows that the formal sector is still dominated by the male population, which reached 63.41 percent. Whereas in the informal sector the male population also dominates with a number that is not much different from the number of formal sectors which is 58.86 percent. While the number of women working in the formal sector is 36.59 percent and the informal sector is 41.14 percent.

Along with the development of the times, economic development is not only seen and measured by the high economic growth but new measures have emerged in economic 
development, one of which is gender-based development. In the economic development of a country, the role of the population consisting of men and women is very necessary, therefore economists judge that development must also include gender equality.

Gender disparities in Indonesia in the employment sector are caused by several factors such as wage gap, education level, and health. "An analysis of gender wage gaps across five developed countries using Glassdoor salary data, identified a gender wage gap of $24.1 \%$ in the United States, with two- thirds of that wage gap explained by differences in workers' characteristics and the most dominant factors being differences in industry and occupational choices (Chamberlain, 2016)" (Adnan and Miaari, 2018).

"This may be explained by the fact that rules and stereotypes that influence women's behavior will lead to significantly identify with the values promulgated by social enterprises. This greater involvement in social activities leads women to become an essential player for promoting such needed initiatives given the impossibility for public institutions to addess all social problems" (Nicolás and Rubio, 2016).

In Indonesia the wage gap between genders has long been in the spotlight, where there is stereotypical thinking of Indonesian culture about women more suitable for doing domestic work, such as taking care of the household and educating children. But slowly there have been many women who have begun to break these thoughts.

"We document the declining gap between the average earnings of women and men in Denmark from 1980 to 2010 . The decline in the earnings gap is driven by increases in hours worked by women as well as a decline in the gender wage gap" (Gallen, Lesner and Vejlin, 2017).

The role of the government in increasing the role of women in economic activities and reducing gender disparities has been quite significant. Legislation and law have been made to provide protection for women workers, one of which is related to wages.

Although there has been an anti-wage discrimination policy since the 1950s, there is still a wage imbalance in Indonesia. In 2011-2015 the wages received by female workers were always lower than the wages of male workers. The causative factor is the assumption that women are not the head of the family so they are given wages as single. In 2015 the average wage of female workers was $\mathrm{Rp} 1.68$ million and the average wage of male workers was $\mathrm{Rp}$ 1.94 million.

In 2015 wage inequality between men and women declined dramatically. The wage inequality was quite high in 2014 at 20.23 percent and decreased to 13.83 percent in 2015 . Although wage inequality between men and women continued to decline, the average female worker still received lower wages compared to male workers.

"The existence of gender discrimination will reduce the capacity growth of an economy and reduce the increase in capacity of living standards because gender inequality will put a burden on the level of productivity, efficiency and progress of an economy "(World Bank, 2005).

"The gender-related growth index is the Gender Development Index. The Gender Development Index is to measure gains in the same dimensions as the Human Development Index, but captures inequalities between women and men". (United Nation Development Program, 2005).

The Gender Development Index is one measure of the success rate of development achievements that have included gender issues. Indonesia's national Gender Development Index value continues to increase from 2010 to 2015 where in 2010 it was 89.42 percent and in 2015 it was 91.03 percent. Although the achievement of the Gender Development Index value has always increased every year, the situation of gender equality in human development 
and employment is still relatively low due to the many factors that affect human resources and employment in Indonesia such as lack of education, health, wages and justice for Indonesian women.

The Ministry of Women's Empowerment and Child Protection explained that to find out the gender gap can be used the gap in the value of the Gender Development Index and the Human Development Index. If the value of the Gender Development Index is the same as the value of the Human Development Index, it means that there is no gender gap, whereas if the value of the Gender Development Index is lower than the value of the Human Development Index, it means gender inequality.

The Human Development Index in Indonesia in 2010 until 2015 continued to increase, in 2010 the Indonesian Human Development Index was 66.50 percent and in 2015 it was 69.55. Papua Province is the province that has the lowest Human Development Index value of 34 provinces in Indonesia with a value of 57.25 in 2015. It needs extra effort that the government must do to improve the quality of life by sharing policies both in terms of health, education and employment.

The economic situation of a region can be seen from the level of economic growth. Economic growth is a process of increasing production capacity of an economy which is achieved in the form of increasing national income.

According to Sukirno (2000), "Economic growth means the development of activities in the economy which causes the goods and services produced in society to increase and the prosperity of the community increases. This ability grows with the realization of an increase in national output continuously accompanied by technological advances and the institutional and ideological adjustments that are needed ".

Increasing economic growth will be more effective when coupled with improving the quality of human resources and reducing the gap between men and women both in their roles and the acquisition of rights to the economy.

Indonesia's economic growth rate from 2010-2015 has decreased. In 2010 the value of economic growth in Indonesia was 6.22 percent and in 2015 it decreased to 4.88 percent. Indonesia's economic growth in 2015 was very low compared to the previous year. The high level of gender will make economic growth low, and vice versa. Economic growth in 2015 was low due to high gender inequality.

From the explanation above, it can be concluded that the value of the Human Development Index and the Gender Development index in Indonesia are still experiencing a gap because the value of the Gender Development Index is higher than the Human Development Index. The value of the male and female labor force in Indonesia is still experiencing a gap because the male workforce is higher than the female workforce and influences the declining economic growth.

Hypothesis

1. It is assumed that the variable number of female labor force has a negative and significant effect on economic growth in Indonesia.

2. It is suspected that the Gender Development Index variable has a positive and significant effect on economic growth in Indonesia.

\section{Method Of Research}

This study uses a quantitative approach aimed at measuring gender disparities and seeing the influence of gender disparities on economic growth. Secondary data used by researchers in the form of panel data, namely a combination of cross-section data (cross-section) of 34 
provinces and time periods (time-series) from 2010-2015. Economic growth in Indonesia was used as the dependent variable in the study, and the gender development index and the number of female labor forces became independent variables. The data collection method used is documentation obtained from the website of the Gender-Based Statistics and Human Development Center in 2016, which has been published.

This study analyzes the influence of the number of female labor forces working on economic growth in Indonesia. Model regression and panel data are made with cross section data and time series, with the equation:

$$
\mathrm{PE}_{\mathrm{rt}}=\beta_{0}+\beta_{1} \mathrm{AKP}_{\mathrm{rt}}+\beta_{2} \mathrm{IPG}_{\mathrm{rt}}+\varepsilon_{\mathrm{rt}} \ldots \ldots .
$$

$$
\begin{aligned}
& \text { Information : } \\
& \begin{array}{ll}
\mathrm{PE} & =\text { Economic growth } \\
\mathrm{AKP} & =\text { Women's work force } \\
\mathrm{IPG} & =\text { Gender Development Index } \\
\beta 0 & =\text { Constants } \\
\beta 1 & =\text { Coefficient } \\
\mathrm{r} & =\text { Cross section } \\
\mathrm{t} & =\text { Time series } \\
\varepsilon & =\text { Error term }
\end{array}
\end{aligned}
$$

\section{Data Analysis And Discussion}

\subsection{Description of data}

\subsubsection{Economic growth}

Economic growth is a process of change or increase of national income from the previous year. The success of economic development in the life of a country's society can be seen from the level of economic growth. The economic growth rate in each province in Indonesia does not always increase but there are also several years of decline, but the increase or decrease in the economic growth rate does not soar but only 1-2\% per year.

\subsubsection{Number of female labor force}

To describe indicators of the labor market in Indonesia, there is a need for employment data sourced from the national labor force survey by the Central Bureau of Statistics, where the aim is to monitor labor dynamics so that decision makers can more quickly take policies to deal with and improve labor issues especially in Indonesia. Women's labor force per province in Indonesia from 2010-2015 does not always increase and does not always decrease, but the female labor force is still small compared to the male workforce.

\subsubsection{Gender Development Index}

The United Nation Development Program (2005) explains that "the Gender Development Index is a gender-related growth index, which aims to measure achievement in the same dimensions as the Human Development Index, but captures inequalities in achievement between women and men". The gender development index value in 2010-2015 in each province in Indonesia has increased continuously every year. But even though the gender development index is always increasing, gender equality and human resources are still relatively low. 


\subsection{Regression Results}

Variables that have a major influence on determining the value of economic growth are the female labor force with a value of -0.074306 and the gender development index, with a value of 1.777289 . If the value of the female labor force increases, the value of economic growth will decrease, for example if the female labor force rises by $1 \%$ then economic growth will decrease by $0.074306 \%$ and if the value of the gender development index increases, the growth rate of the economy will also increase, for example the value of the gender development index increases by $1 \%$, the value of economic growth will increase by $1.777289 \%$.

\subsubsection{Assessment}

a. The coefficient of determination (R2)

$\mathrm{R}^{2}$ is 0.048987 or $0.04 \%$. then the female labor force variable and gender development index affect economic growth by only $0.04 \%$, the remaining $0.96 \%$ is influenced by other variables such as education, population growth, investment and so on.

b. Correlation coefficient $(\mathrm{R})$

From the results of the first data generated a regression equation, then analyzed using the auto regression model results as follows:

$$
\mathrm{PE}_{\mathrm{t}}=-6.267038+-0.074306 \mathrm{AKP}_{\mathrm{t}}+1.777289 \mathrm{IPG}_{\mathrm{t}}
$$

Interpretation of the model or hypothesis taken from the regression results is:

1. That the female labor force variable has a negative and significant influence on economic growth because the female labor force coefficient value is below 0.05 , namely the value of -0.074306 . That is, if the female labor force rises by $1 \%$ then economic growth will decrease by $0.074306 \%$.

2. That the gender development index variable has a positive and significant effect on economic growth with a coefficient value of 1.777289 . That is, if the value of the gender development index rises by $1 \%$ then economic growth will also increase by $1.777289 \%$.

\subsubsection{Testing}

a. Partial test (t-test)

1. Women's Labor Force (AKP)

The tcount is -2.182047 and the probability value is 0.0303 (below $\alpha 5 \%$ ). This shows that the relationship between the female labor force and economic growth in Indonesia is negative and significant.

2. Gender development index (IPG)

The tcount is 2.664719, this shows that the relationship between the gender development index and economic growth in Indonesia is positive and significant.

b. Simultaneous test (Test - F)

Based on the regression results obtained a statistical $F$ value of 4.893508 with a probability value of $0.008466<\alpha 5 \%$, this indicates that all independent variables together have a significant effect on the dependent variable.

c. Multicollinearity test

It can be seen from the test results that there is no multicollinearity in the regression model. Because the correlation coefficient between the independent variables is $<0.80$.

d. Heteroscedacity test 
From the heteroscedacity test using the glejser test it can be seen that the regression is free from heteroscedacity, where the probability value of the PPA variable is 0.9588 and the GPA is $0.8471>$ of $\alpha 0.05$.

e. Autocorrelation Test

From the results of the Durbin Watson test this linear regression has no autocorrelation, where using $\mathrm{k}=2$ and $\mathrm{n}=193$, from the Durbin-Watson table it is known that $\mathrm{dL}=1.7435$ and $\mathrm{dU}=1.7853$ can be seen that the $\mathrm{DW}$ value is $1.093192>$ from $\mathrm{dU}$ of 1.7853 then there is no autocorrelation

f. Uji Hausman

From the results of the Hausman test panel data regression is better to use the fixed effect model, because the probability value of the chi square cross-section is smaller.

\subsection{Discussion}

\subsubsection{Women's Work Force}

The regression results show that the Women's Labor Force variable has a negative and significant influence on economic growth in Indonesia. This is different from the research conducted by Rahmi Fuji Astuti Harahap (2014) entitled "Analysis of the Effects of Gender Inequality on Economic Growth in West Java". Where the level of male and female labor force participation has a positive and significant effect on economic growth in West Java.

\subsubsection{Gender Development Index}

The regression results show that gender development index variables have a positive and significant effect on economic growth in Indonesia. In line with the research conducted by Rahmi Fuji Astuti Harahap (2014) with the research title "Analysis of the effect of gender inequality on economic growth in West Java, with the results of the study of all independent variables influencing the dependent variable".

\section{Conclusion}

a. Female Labor Force variables have a negative and significant influence on economic growth in Indonesia.

b. The gender development index variable has a positive and significant relationship to economic growth in Indonesia.

c. Based on the estimation model, the female labor force variable and the gender development index variable influence the Economic Growth in Indonesia, with the R2 value of 0.048987 .

\section{References}

[1] Adnan, W. and Miaari, S. H. (2018) 'Voting patterns and the gender wage gap', Journal of Economic Behavior and Organization. Elsevier B.V., 146, pp. 222-247. doi: 10.1016/j.jebo.2017.12.027.

[2] Badan Pusat Statistik. www.bps.go.id

[3] Badan Pusat Statistik. 2016, Berbasis, Survei Angkatan Kerja Nasional, Jakarta.

[4] Badan Pusat Statistik , 2016, Indikator pasar tenaga kerja Indonesia, Jakarta.

[5] Ekonomi, I., Studi, D. A. N. and Diponegoro, U. (2014) GENDER TERHADAP PERTUMBUHAN.

[6] Gallen, Y., Lesner, R. V and Vejlin, R. (2017) 'The Labor Market Gender Gap in 
Denmark: Sorting Out the Past 30 Years', IZA Discussion Paper. Elsevier B.V., 56(October 2018), pp. 58-67. doi: 10.1016/j.labeco.2018.11.003.

[7] Harahap, Rahmi Fuji Astuti, 2014. Analisis pengaruh kesenjangan gender terhadap pertumbuhan ekonomi di Jawa tengah. skripsi. Fakultas ekonomika dan bisnis universitas diponegoro. Semarang.

[8] Mosse, Julia Clever, 2003. Gender dan Pembangunan. Pustaka pelajar, Yogyakarta.

[9] Nicolás, C. and Rubio, A. (2016) 'Social enterprise: Gender gap and economic development', European Journal of Management and Business Economics. AEDEM, 25(2), pp. 56-62. doi: 10.1016/j.redeen.2015.11.001.

[10] Rai, S. M., Brown, B. D. and Ruwanpura, K. N. (2019) 'SDG 8: Decent work and economic growth - A gendered analysis', World Development. Elsevier Ltd, 113, pp. 368-380. doi: 10.1016/j.worlddev.2018.09.006.

[11] Schober, T. and Winter-Ebmer, R. (2011) 'Gender wage inequality and economic growth: Is there really a puzzle?-A comment', World Development. Elsevier Ltd, 39(8), pp. 1476-1484. doi: 10.1016/j.worlddev.2011.05.001.

[12] Sukirno, Sadono. 2000. Pengantar Teori Makroekonomi. PT. Raja Grafindo Persada, Jakarta.

[13] Sukirno, Sadono. 2008. Mikroekonomi. Edisi ketiga. Raja Grafindo, Jakarta.

[14] United Nation Development Program, 2005. Indeks Pembangunan Manusia. www.undp.org. 2 April 2016.

[15] United Nation Development Program, 2004. Indeks Pembangunan Manusia. www.undp.org. 2 April 2016

[16] World bank, 2005. Pembangunan berprespektif. Dian rakyat, Jakarta. 